\title{
Anatomy of Adventitious Root Formation in Microcuttings of Malus domestica Borkh. 'Gala'
}

\author{
James F. Harbage ${ }^{1}$, Dennis P. Stimart ${ }^{2}$, and Ray F. Evert ${ }^{3}$ \\ Department of Horticulture, 1575 Linden Drive, University of Wisconsin, Madison, WI 53706
}

Additional index words. apple, auxin, epoxy resin, IBA, micropropagation, sucrose, thin sections

\begin{abstract}
Anatomical events of adventitious root formation in response to root induction medium, observing changes during induction and post-induction stages, were made with microcuttings of 'Gala' apples. Shoot explants on root induction medium containing water, $1.5 \mu \mathrm{M} \mathrm{IBA,} 44 \mathrm{~mm}$ sucrose, or $1.5 \mu \mathrm{M}$ IBA + 44 mM sucrose after 4 days of treatment averaged 0, 0.2, 2.2, and 11.9 meristemoids per microcutting, respectively. Meristemoids formed in response to sucrose were confined to leaf gaps and traces. Time-course analysis of root induction with $1.5 \mu \mathrm{M} \mathrm{IBA}+44 \mathrm{~mm}$ sucrose over 4 days revealed that some phloem parenchyma cells became densely cytoplasmic, having nuclei with prominent nucleoli within 1 day; meristematic activity in the phloem was widespread by 2 days; continued division of phloem parenchyma cells advanced into the cortex by 3 days; and that identifiable root primordia were present by 4 days. Cell division of pith, vascular cambium, and cortex did not lead to primordia formation. Meristematic activity was confined to the basal 1 mm of microcuttings. Timecourse analysis of post-induction treatment revealed differentiation of distinct cell layers at the distal end of primordia by 1 day; primordia with a conical shape and several cell layers at the distal end by 2 to 3 days; roots with organized tissue systems emerging from the stem by 4 days; and numerous emerged roots by 6 days. Root initiation was detectable within 24 hours and completed by day 4 of the root induction treatment and involved only phloem parenchyma cells. Chemical names used: $1 \boldsymbol{H}$-indole3-butryic acid (IBA).
\end{abstract}

Induction of adventitious root formation by auxin allows clonal propagation of many plant species (Hartmann et al., 1990). This process varies by genotype, with woody species generally more difficult to root than herbaceous (Hackett, 1988). Barriers to adventitious root formation in woody species can be eliminated often by micropropagation (Lyrene, 1981; Rugini and Verma, 1983; Sriskandarajah et al., 1982); however, some species remain recalcitrant (Zimmerman and Fordham, 1985).

Root primordia initiation and development of organized roots generally occur before emergence from the stem (Esau, 1977). Microcuttings of $M$. domestica have been used to study root formation (Zimmerman and Fordham, 1985), but anatomical observations are lacking. Such studies clarify developmental events leading to root formation. The duration and location of these events can vary between taxa and even between conventional and micropropagated material (Lovel and White, 1986). Current methods of microtechnique for light microscopy that involve epoxy embedding and thin sectioning allow observation of subtle differences between cells less evident in thicker paraffin sections.

For optimizing root induction medium for microcuttings of $M$. domestica, best results were obtained with $1.5 \mu \mathrm{M}$ IBA plus 43.8 mM sucrose delivered as a liquid for 3 to 7 days in dark at 30C followed by post-induction transfer to light at $23 \mathrm{C}$ in medium without sucrose or IBA (Zimmerman and Fordham, 1985). Other work demonstrated improved rooting when microcuttings were transferred to $22 \mathrm{~mm}$ sucrose plus half-strength MS minerals lacking Fe during the post-induction treatment (Harbage, 1991). Both studies used macroscopic observations of root emergence, beginning 10 to 14 days after initial treatment. Therefore, association between medium treatments and developmental stage was lacking.

This study was undertaken at the microscopic level to examine

Received for publication 28 Sept. 1992. Accepted for publication 9 Jan. 1993. The cost of publishing this paper was defrayed in part by the payment of page charges. Under postal regulations, this paper therefore must hereby be marked advertisement solely to indicate this fact.

'Graduate Research Assistant.

${ }^{2}$ Professor.

${ }^{3}$ Professor, Dept. of Botany. development of adventitious roots in response to root induction media, observing changes during induction and post-induction stages.

\section{Materials and Methods}

\section{Shoot culture}

Stabilized proliferating shoot cultures of 'Gala' apple were obtained from R.H. Zimmerman (USDA/ARS, Beltsville, Md.) in June 1987. Cultures were maintained by transfer of single shoots or shoot clumps onto fresh medium containing MS minerals (Murashige and Skoog, 1962), $100 \mu \mathrm{M}$ Fe-EDTA, $0.56 \mathrm{~mm}$ myoinositol, $1.2 \mu \mathrm{M}$ thiamine $\mathrm{HCl}, 1.3 \mu \mathrm{M}$ gibberellic acid $\left(\mathrm{GA}_{3}\right), 0.49$ $\mu$ м IBA, $4.44 \mu \mathrm{M} N$-(phenylmethyl)- $1 \mathrm{H}$-purine-6-amine (BA), 88 mM sucrose, and $0.7 \%$ Difco Bacto-agar. Cultures were incubated under $40 \mu \mathrm{mol} \cdot \mathrm{m}^{-2} \cdot \mathrm{s}^{-1}$ continuous cool-white fluorescent light at 21 or $29 \mathrm{C}$.

\section{Root induction treatment}

Apical shoot explants (microcuttings) were excised from proliferating shoot masses 30 to 35 days old and submerged in sterile distilled water to prevent desiccation. Shoot lengths were adjusted by cutting below the fifth node down from the uppermost-emerging leaf to establish physiological uniformity. Individual shoots were placed in $25 \times 90$-mm glass shell vials in plastic supports, with the basal $4 \mathrm{~mm}$ of each shoot in liquid medium and capped with Kaputs (Belco Biotechnology, Vineland, N.J.). Vials were placed in test tube racks in darkness at $30 \mathrm{C}$ for 0 to 4 days.

Comparisons were made of microcutting response to root induction medium components evaluated previously by counts of emerged roots (Harbage, 1991). For this part of the study, microcuttings originated from cultures grown at $21 \mathrm{C}$. Root induction medium treatments were water, $1.5 \mu \mathrm{M}$ IBA, $44 \mathrm{~mm}$ sucrose, and IBA + sucrose. Media pH was 5.5. In addition to a 4-day root induction treatment, 8-day treatments were included for sucrose and IBA + sucrose. Localized clusters of meristematic cells (meristemoids; Torrey, 1966) were detected with a microscope 
and counted. In a second study, the time course of anatomical events occurring in response to root induction treatment was followed. Microcuttings from cultures held at 21 or $29 \mathrm{C}$ were used at separate times, with all treatments evaluated on microcuttings from a single temperature at any one time. Microcuttings were treated with IBA + sucrose for $0,1,2,3$, and 4 days.

\section{Post-induction treatment}

Post-induction treatment followed after 4 days of root induction treatment by transfer of microcuttings to $3 \mathrm{ml}$ of liquid medium containing one-half $\times$ MS minerals (minus Fe) and $22 \mathrm{~mm}$ sucrose in vials and supports described previously. Post-induction treatment occurred under $30-\mu \mathrm{mol} \cdot \mathrm{m}^{-2} \cdot \mathrm{s}^{-1} \mathrm{cool}-$ white fluorescent light at $23 \mathrm{C}$. Anatomical events during post-induction treatment were observed in shoots after 1, 2, 3, 4, and 6 days. All treatments were evaluated on microcuttings from culture at a single temperature (21 or 29C) at any one time.

\section{Microtechnique}

Wax embedment. Initially, tissues from the root-induction and post-induction treatments were processed following wax embedding protocols. Tissues were fixed in 1 formalin : 1 acetic acid : 9 ethanol : 9 water (FAA), dehydrated in a graded ethanol or tertiary butyl alcohol series, infiltrated with Amerafin embedding wax (Baxter, McGaw Park, Ill.), and poured into paper embedding molds. When a graded ethanol series was used for dehydration, xylene was used as a transition solvent before wax infiltration. Embedded tissue was mounted on wood blocks and sectioned at 5 to $10 \mu \mathrm{m}$ on a Spencer 820 rotary microtome (American Optical, Buffalo, N.Y.). Sections were mounted on slides with Haupt's adhesive (Johansen, 1940), stained in saffranin-fast green, and covered with a coverslip. A minimum of 10 microcuttings were used for each medium treatment and duration.

Epoxy resin embedment. More detailed observations of primordium initiation were made on epoxy resin-embedded material. Microcuttings collected in 0.05 m cacodylate buffer ( $\mathrm{pH} 7.0)$ after $0,1,2,3$, and 4 days of root induction treatment were fixed in 5\% glutaraldehyde in $0.05 \mathrm{M}$ cacodylate buffer, and post-fixed in $2 \%$ osmium tetroxide in $0.05 \mathrm{M}$ cacodylate buffer. Tissues were dehydrated in a graded acetone series and then infiltrated with Spurr's low-viscosity embedding medium (hard recipe; Spurr, 1969). Both transverse and longitudinal sections at 1 to $2 \mu \mathrm{m}$ were obtained with glass knives on a Porter-Blum MT-2 ultramicrotome (Sorval, Wilmington, Dela.). Sections were mounted on slides, stained with $0.5 \%$ toluidine blue $\mathrm{O}$, and covered with a coverslip. Observations and photographs were taken using bright field illumination on a Zeiss Axiophot microscope (Carl Zeiss, Oberkochen, Germany).

\section{Results}

\section{Root induction-media effects}

Root initiation depended on root induction medium components (Table 1). Initiation of root meristemoids occurred in the basal $1 \mathrm{~mm}$ of the microcuttings regardless of treatment. Initiation in sucrose alone or in IBA + sucrose for 8 days resulted in no change in location or number of meristemoids as compared to 4-day treatment (Table 1).

Microcuttings treated with water during root induction treatment showed little or no meristematic activity or meristemoid
Table 1. Influence of root induction medium components on number of root meristemoids present in microcuttings of 'Gala' apple after 4 or 8 days of induction treatment.

\begin{tabular}{lcc}
\hline \hline & \multicolumn{2}{c}{ No. root primordia } \\
\cline { 2 - 3 } Initiation medium & 4 days & 8 days \\
\hline Water & $0(0)^{\mathrm{z}}$ & --- \\
$1.5 \mu \mathrm{M}$ IBA & $0.2(0.2)$ & --- \\
$44 \mathrm{mM}$ sucrose & $2.2(0.5)$ & $2.1(0.7)$ \\
IBA + sucrose & $11.9(0.6)$ & $11.6(0.9)$ \\
\hline
\end{tabular}

${ }^{\mathrm{z}}$ Standard error of mean based on 10 microcuttings per treatment.

initiation (Fig. 1A). Those treated with $1.5 \mu \mathrm{M}$ IBA resembled those treated with water, showing little meristematic activity (Fig. 1B), with only one root meristemoid being found in the samples examined. Treatment in $44 \mathrm{~mm}$ sucrose resulted in initiation of distinct adventitious root meristemoids by 4 days in $80 \%$ of the microcuttings, with an average of 2.2 meristemoids per shoot. These meristemoids were associated with interfascicular regions and often bordered leaf traces and gaps (Fig. 1C). Treatment in 1.5 $\mu \mathrm{M}$ IBA $+44 \mathrm{~mm}$ sucrose resulted in root meristemoids in all microcuttings, with an average of 11.9 meristemoids per microcutting (Fig. 1D). Meristemoids were initiated in phloem tissue around the ring of vascular bundles. They were not associated specifically with leaf gaps.

\section{Root induction-time course study}

No difference in response was observed between microcuttings from cultures held at 21 or $29 \mathrm{C}$.

0 days. Transverse sections of nontreated stems at 0 days contained 16 to 18 collateral vascular bundles forming a ring around the pith in the basal 1 to $2 \mathrm{~mm}$ of the microcutting (Fig. 2A). Phloem was separated from xylem by a cambial region of three to four cell layers (Fig. 2B). A cambial region was present in some of the interfascicular regions. Xylem consisted entirely of vessel members and parenchyma cells, with the number of mature vessels with secondary thickenings depending on developmental age of the bundle. Phloem consisted of sieve elements, companion cells, and parenchyma cells. Metaphloem sieve elements had thick nacreous walls, some of which almost occluded the lumina. Secondary phloem formation was hardly underway in some bundles and absent in most. Cortex surrounding the vascular cylinder consisted mainly of large parenchyma cells, the inner layer of which formed an ill-defined starch sheath (Fig. 2A). The outer two to three layers of cortical tissue were composed of thick-walled collenchyma cells. A uniseriate epidermis surrounded the cortex. All parenchymatous elements of the stem, with the possible exception of the companion cells, were highly vacuolate.

1 day. After 1 day of root induction treatment there appeared a few, small clusters of cells with densely staining cytoplasm and nuclei with prominent nucleoli (Fig. $3 \mathrm{~A}$ and B). These clusters of parenchymatous cells were located primarily in metaphloem and infrequently in the cambial region or xylem, in the basal $300 \mathrm{~m}$ of microcuttings.

2 days. After 2 days of root induction treatment, microcuttings showed obvious changes relative to microcuttings at 0 and 1 day (Fig. $4 \mathrm{~A}$ and B). Most phloem parenchyma cells showed signs of meristematic activity, being less highly vacuolate, more densely cytoplasmic, and with nuclei containing large prominent nucleoli. Mitotic figures were common in these cells (Fig. 4A). Metaphloem parenchyma cells were affected most, having increased in number and size over microcuttings treated for 0 or 1 day. Periclinal 

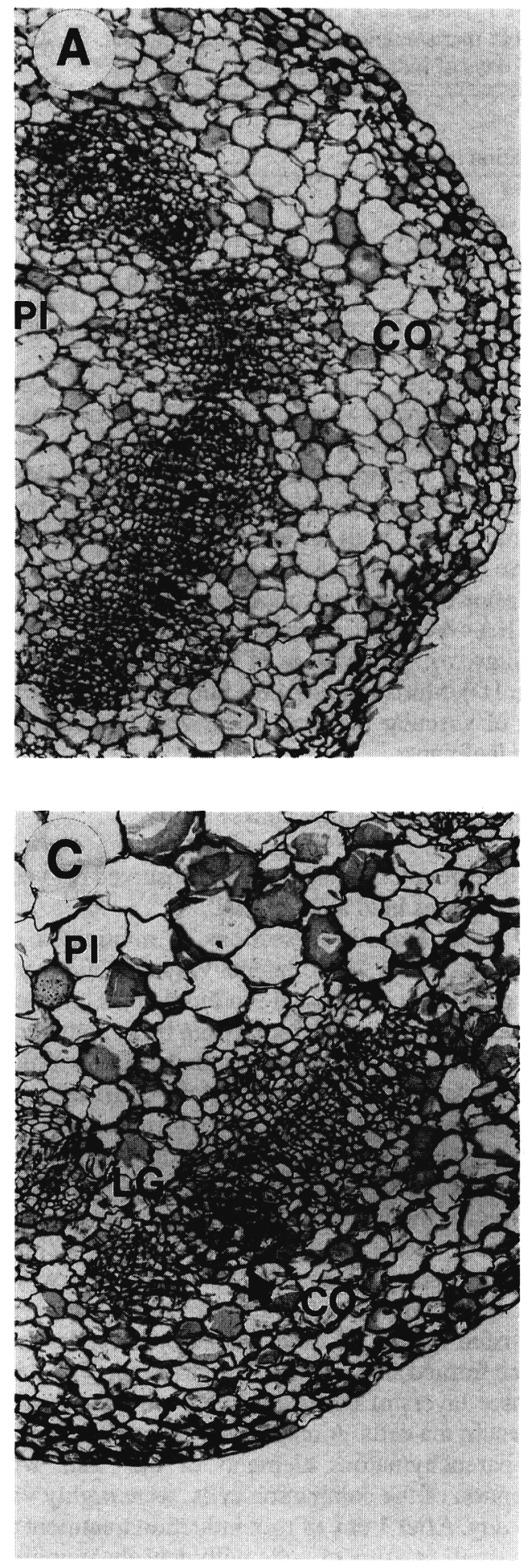
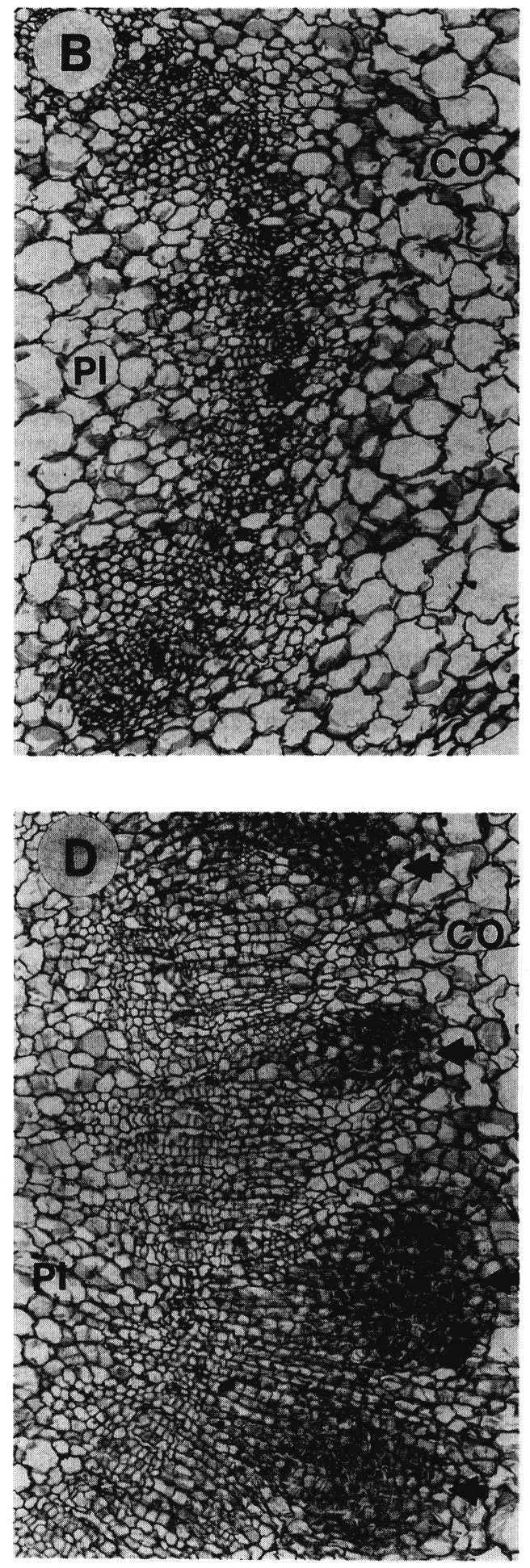

Fig. 1. Transverse sections of microcuttings of ' Gala' apple, 300 to $500 \mu \mathrm{m}$ above the basal end, after 4 days in root induction medium containing (A) water, (B) $1.5 \mu \mathrm{M}$ IBA, (C) $44 \mathrm{~mm}$ sucrose, and (D) $1.5 \mu \mathrm{M}$ IBA $+44 \mathrm{~mm}$ sucrose. Magnification $=\times 160$. Abbreviations: cortex (CO), leaf gap (LG), and pith (PI). Arrows indicate meristemoids.

divisions (and some oblique divisions) accompanied by radial expansion resulted in formation of radial files of cells from the cambium outward. Metaphloem sieve elements remained in small groups of four to five, surrounded by meristematic cells. Most protophloem sieve elements were crushed, possibly in part by enlarging phloem parenchyma cells and partly by intruding primary phloem fiber primordia. Phloem fiber precursors were not affected by root induction treatments. Some xylem parenchyma cells exhibited decreased vacuolation, increased density, and nuclei with prominent nucleoli; however, these cells did not show signs of dividing. Activity was restricted to the basal $1000 \mu \mathrm{m}$ of microcuttings.

3 days. After 3 days of root induction treatment, meristematic tissue bulged into the cortex, compressing cortical cells in its path (Fig. $5 \mathrm{~A}$ and B). Planes of cell division were now oriented in many directions and densely cytoplasmic meristematic cells were iso- 

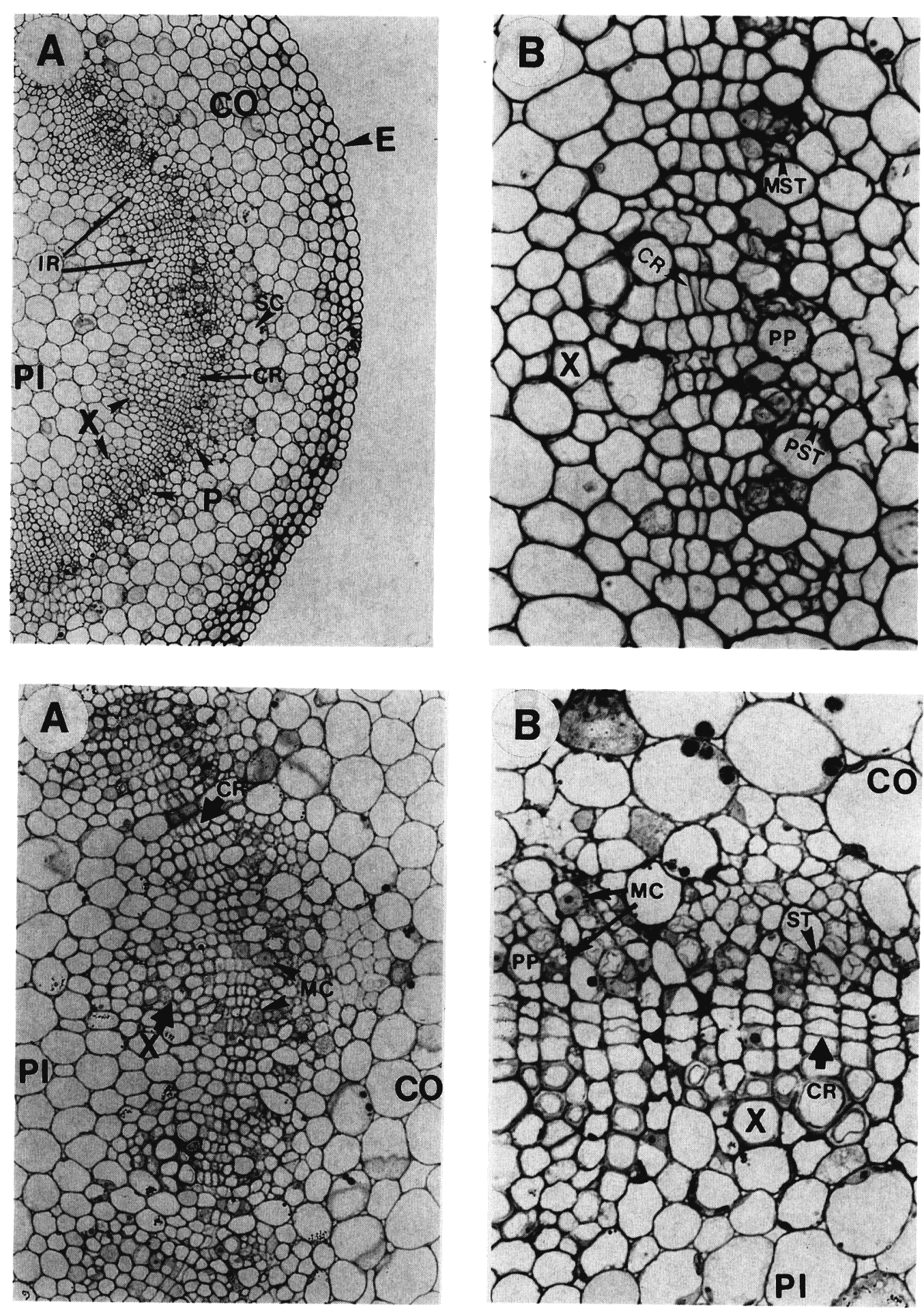

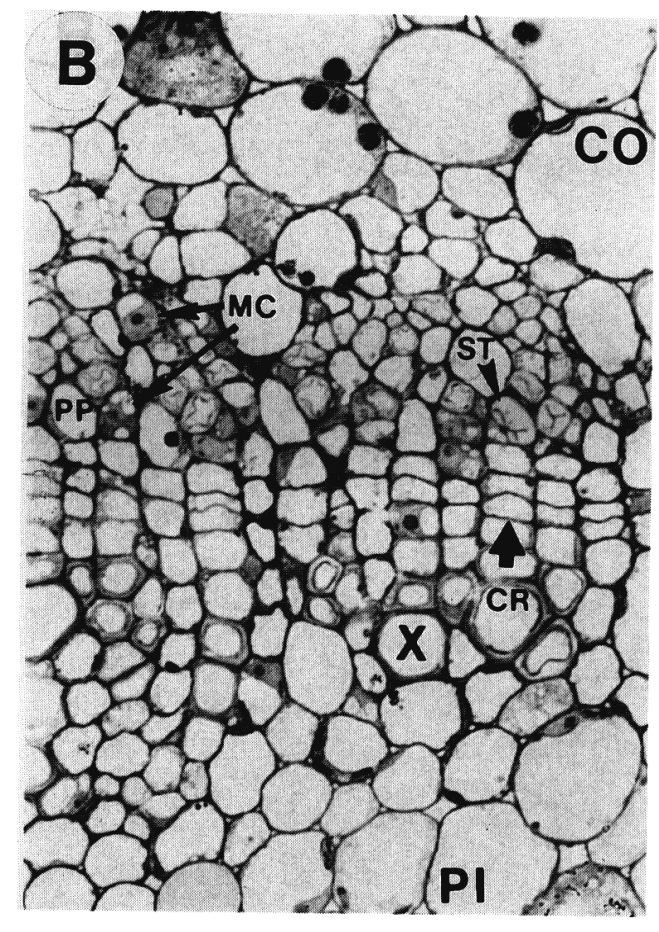

Fig. 2. Transverse sections of microcuttings of 'Gala' apple before root induction treatment (i.e., 0 days) at $(A)=\times 160$ and (B) $=\times 800$. Abbreviations: cortex $(\mathrm{CO})$ cambial region (CR), epidermis (E), interfascicular region (IR), metaphloem sieve tube (MST), phloem (P), pith (PI), phloem parenchyma cell (PP), protophloem sieve tube (PST), xylem (X), and starch sheath cell (SC).
Fig. 3. Transverse sections of microcuttings of 'Gala' apple after root induction treatment with $1.5 \mu \mathrm{M}$ IBA + $44 \mathrm{~mm}$ sucrose for 1 day taken $300 \mu \mathrm{m}$ above the base. Magnification: $(\mathbf{A})=\times 320$ and $(\mathbf{B})=$ $\times 800$. Abbreviations: cortex (CO), cambial region (CR), meristematic cell (MC), pith (PI), metaphloem sieve tube (ST), and xylem (X). diametric in shape. Interior to these cells, the relatively highly vacuolated cells of the cambial region were arranged in radial files. Meristematic tissue remained restricted to the basal $1000 \mu \mathrm{m}$ of microcuttings.

4 days. After 4 days of root induction treatment, a cambial region per se was no longer present. Cells of the cambial region adjacent to the developing meristem were not fusiform, but subdivided and expanded, and appeared as strands of highly vacuolated parenchyma cells (Fig. 6D). Meristematic regions, separated by files of radially elongated cells, could be identified as root primordia (Fig. $6 \mathrm{~A}$ and C). Metaphloem sieve elements remained intact in some primordia (Fig. 6C), but most were crushed.
Pith cells at the level of the root primordia had divided, but underwent little or no apparent enlargement (Fig. 6 A and B); hence, pith did not increase in size from this activity. Most pith cells in the region of meristematic activity contained starch grains, whereas those above this region contained few, if any. The region of meristematic activity in the pith did not extend as high, vertically, as that external to it. By now, some cortical cells had divided, but they were not involved with formation of root primordia.

After 4 days of root induction treatment, most meristematic activity was restricted to the basal $1000 \mu \mathrm{m}$ of microcuttings (Fig. $6 \mathrm{~B})$; transverse sections above the meristematic activity were similar to those of the control (Fig. 6B). 
Fig. 4. (A) Transverse and (B) longitudinal sections of microcuttings of 'Gala' apple after 2 days of root induction treatment with $1.5 \mu \mathrm{M}$ IBA $+44 \mathrm{~mm}$ sucrose, from the meristematic region, i.e., basal $1 \mathrm{~mm}$. Magnification: $(\mathbf{A})=$ $\times 320$ and $(B)=\times 160$. Abbreviations: cortex (CO), cambial region (CR), dividing cells $(\mathrm{DC})$, phloem $(\mathrm{P})$, pith (PI), metaphloem sieve tube (ST), and xylem (X)

Fig. 5. (A) Transverse and (B) longitudinal sections of microcuttings of 'Gala' apple after root induction treatment with $1.5 \mu \mathrm{M} \mathrm{IBA}+44 \mathrm{~mm}$ sucrose for 3 days taken from the meristematic region. Magnification: $(\mathbf{A})=\times 320$ and $(B)=\times 160$. Abbreviations: cortex (CO), epidermis (E), meristemoid (M), meristematic region (MR), phloem $(\mathrm{P})$, pith (PI), and xylem (X).
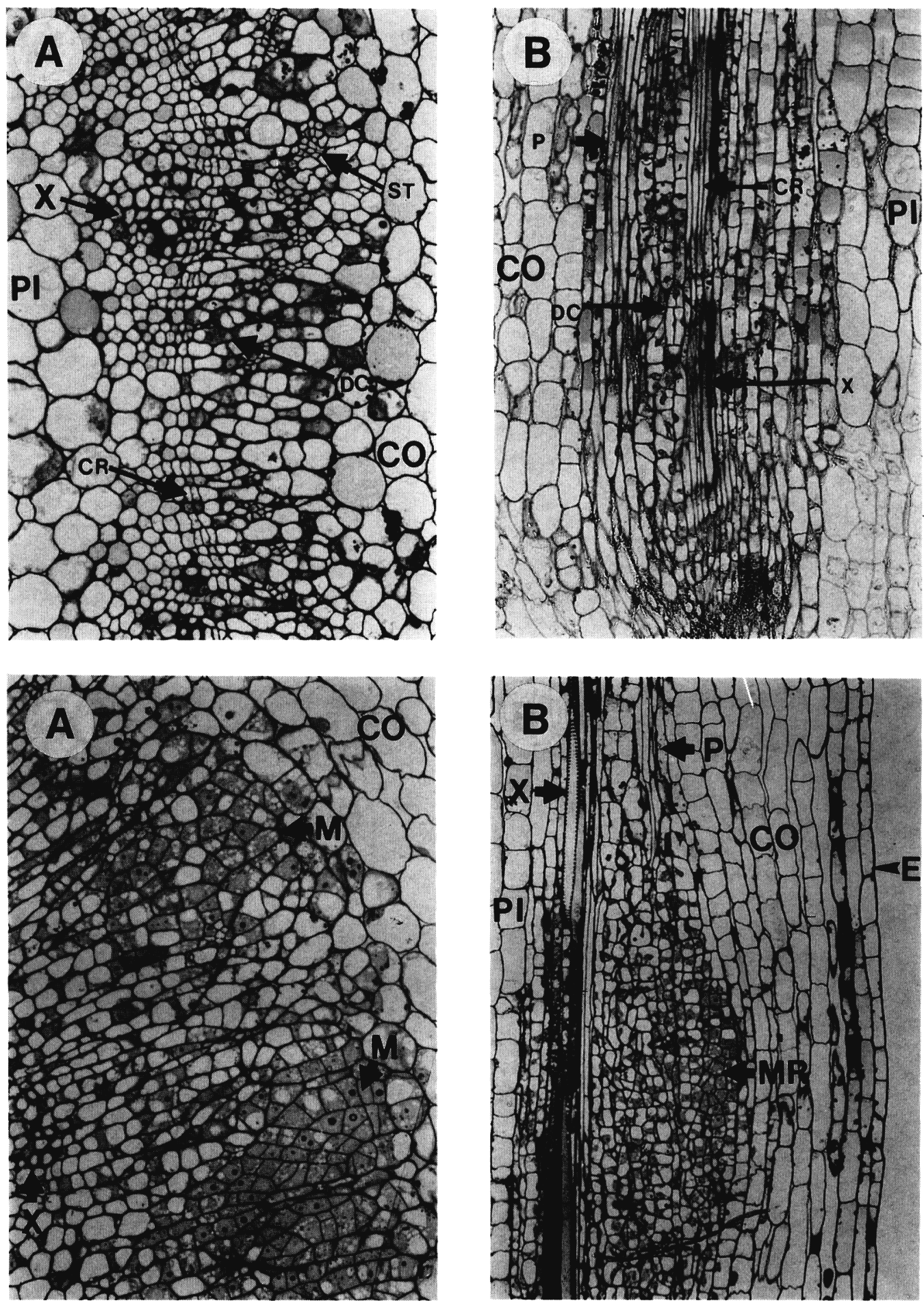

\section{Post-induction-time course study}

No difference in response was observed between microcuttings held at 21 and $29 \mathrm{C}$.

1 day. Microcuttings transferred to the post-induction treatment after 4 days of root induction showed one notable change after 1 day in new conditions: One to two distinct cell layers were present at the distal end of the primordia (Fig. 7A).

2 days. After 2 days of post-induction treatment, outer cells at the distal end of some root primordia appeared to have gone through extensive periclinal divisions, resulting in formation of several distinct cell layers (Fig. 7B). Root primordia began to assume a somewhat conical shape, with the apex extending outward into the cortex. Parts of the epidermis and outer cortical layers were being sloughed.

3 days. After 3 days of post-induction treatment, organization was similar to that after 2 days of development, with several distinct layers of cells terminating most root primordia (Fig. 7D).

4 days. After 4 days of post-induction treatment, the vascular cylinder (procambium) and cortex (ground meristem) were blocked out, and the apical meristem could be distinguished from the root cap in some primordia (Fig. 7C). Additionally, xylem elements extended from the base towards the tips of some root primordia for varying distances, depending on degree of development of indi- 

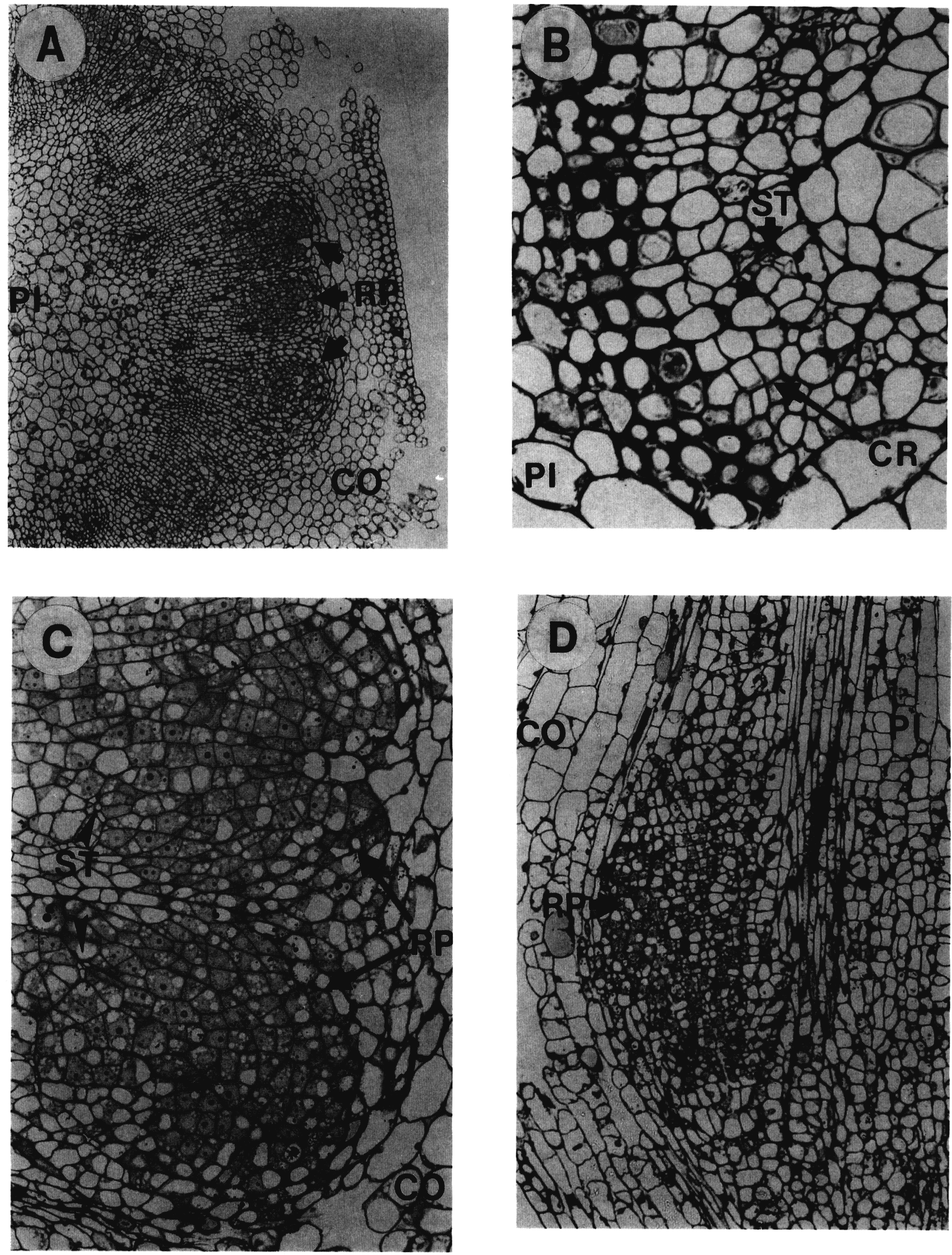

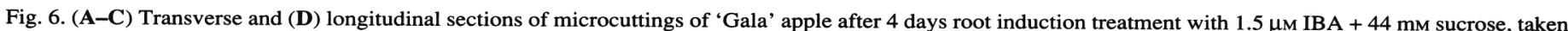
from the meristematic region $(\mathbf{A}, \mathbf{C}$, and $\mathbf{D})$ or above the meristematic region $(\mathbf{B})$. Magnification: $(\mathbf{A})=\times 100,(\mathbf{B})=\times 1000,(\mathbf{C})=\times 400$, and $(\mathrm{D})=\times 200$. $\mathrm{Abbreviations:}$ cortex (CO), cambial region (CR), pith (PI), root primordium (RP), and metaphloem sieve tube (ST). 

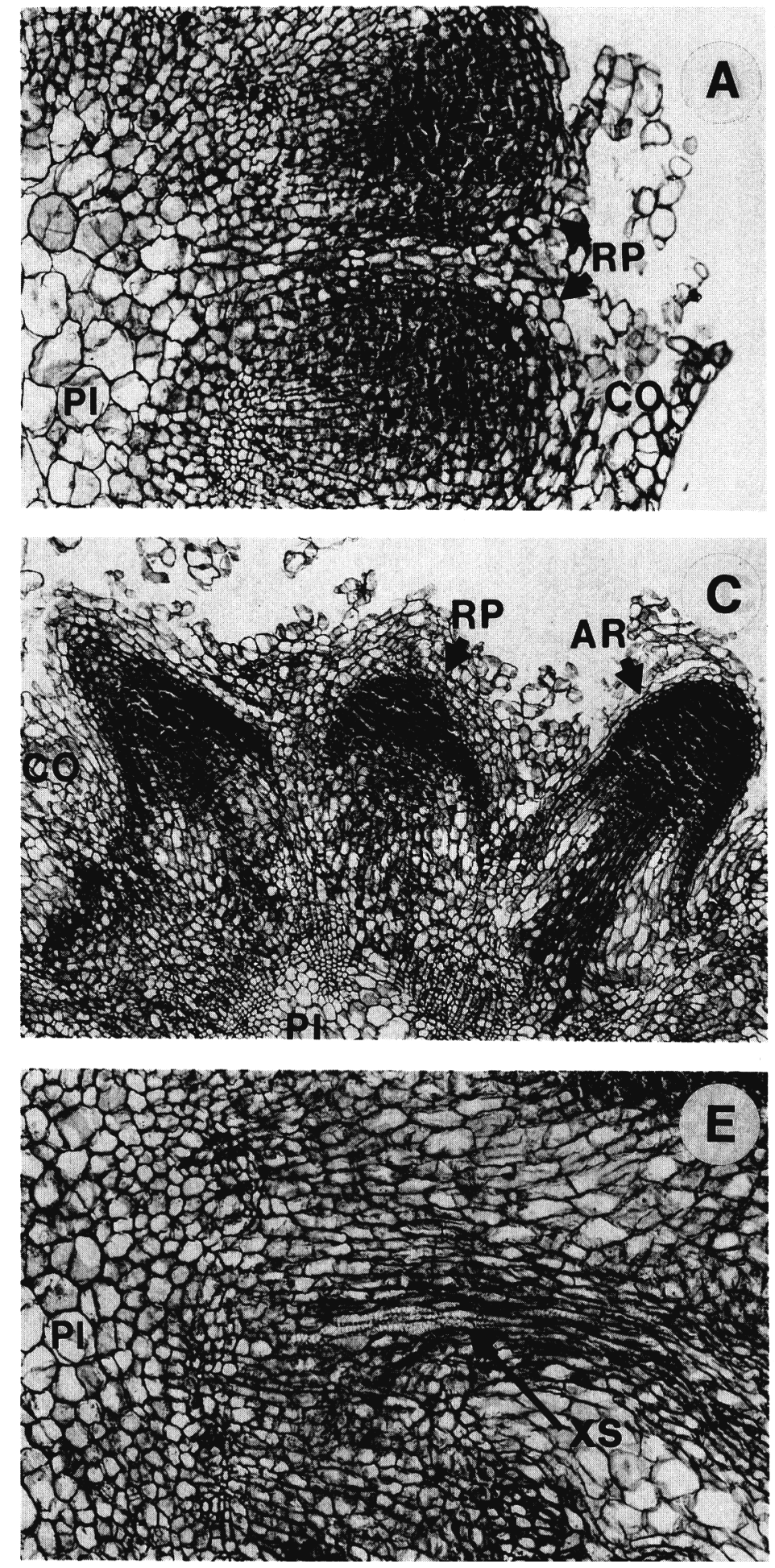
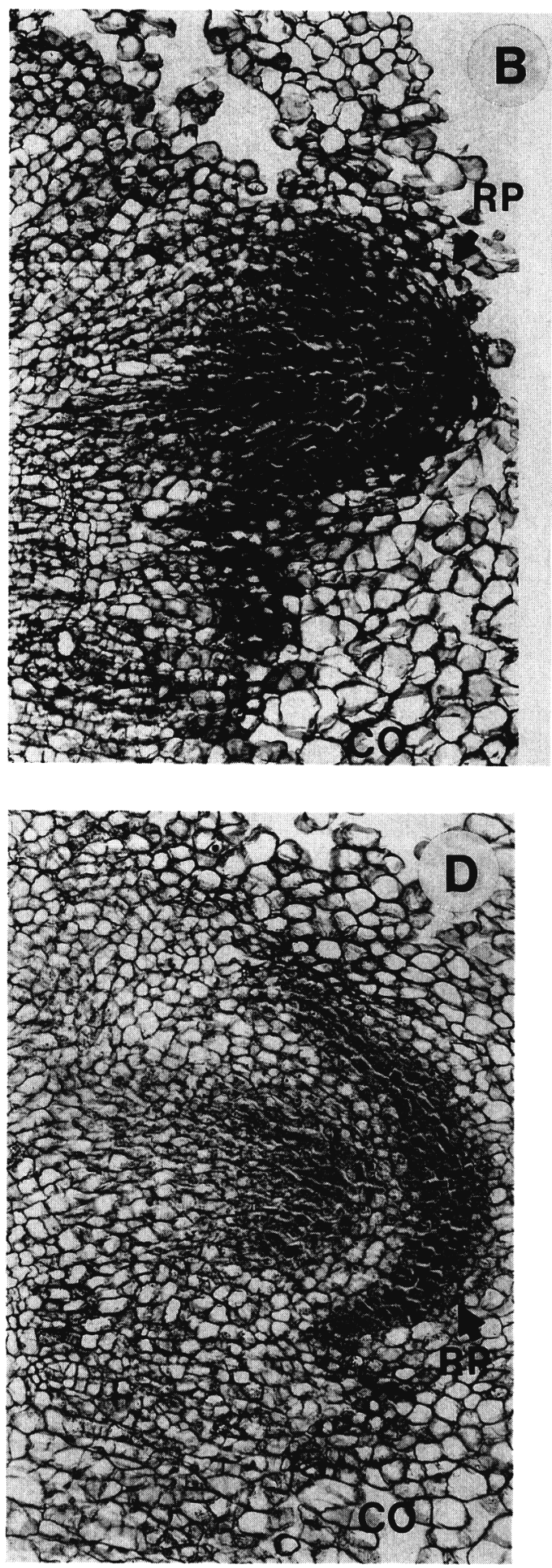

Fig. 7. Transverse sections of microcuttings of 'Gala' apple after $(\mathbf{A}) 1,(\mathbf{B}) 2,(\mathbf{C}) 3$, and $(\mathbf{D}$ and $\mathbf{E}) 4$ days of post-induction treatment. Magnification: $(\mathbf{A}-\mathbf{C}, \mathbf{E})=\times 160$ and $(D)=\times 80$. Abbreviations: adventitious root $(A R)$, cortex $(C O)$, pith $(\mathrm{PI})$, root primordium $(\mathrm{RP})$, and xylem strand $(\mathrm{XS})$.

vidual roots (Fig. 7E). Some roots were emerging from the stem. 6 days. After 6 days of development treatment, numerous roots had emerged from the base of microcuttings and some were still emerging. All roots appeared to have developed normally.

\section{Discussion}

This study showed that medium components that induced root formation in microcuttings of 'Gala' apples did so by triggering the initiation of cell division leading to formation of root primordia (root initiation) in regions where none existed previously. Timecourse analysis of the induction phase indicated that phloem parenchyma cells responded to treatment within 1 day and led to identifiable root primordia by the end of 4 days of induction. The number and location of root primordia remained unchanged when root induction treatment was extended to 8 days. Time-course 
analysis of the post-induction phase indicated that root formation shifted (within 1 day) from initiation of primordia to development of organized root tissue systems. Organized roots with vascular systems continuous with that of the stem could be observed by the time they emerged.

Previous work with microcuttings of $M$. domestica (Zimmerman and Fordham, 1985) showed that root induction medium could be simplified to sucrose and auxin (IBA was optimal) when delivered as in the present study. Our results show that medium components were required for initiation of root primordia (11.9 per shoot) throughout the phloem parenchyma at the base of microcuttings. Elimination of IBA resulted in initiation of few roots $(2.2$ per shoot), and these were associated with leaf gaps and interfascicular regions. Preformed root primordia in field-grown $M$. domestica (Swingle, 1927) and layering-induced roots on M. pumila Mill. (Doud and Carlson, 1977) were associated also with leaf gaps. previous work found that adventitious root formation in response to sucrose occurred at basal ends of microcuttings, but was eliminated by shoot tip removal and was reinitiated by IBA supplied apically unless polar transport inhibitors were applied (Harbage, 1991). This result suggests root primordia initiation in sucrose required polar transport of an auxin-like substance from the shoot tip to the base of the microcutting, with the auxin-like substance moving down leaf traces and accumulating at the base of the severed shoot, where it triggered root formation.

Initiation of cell division by the rooting treatment took place in parenchyma cells of the phloem, cortex, cambial region, xylem, and pith (Figs. 1-6). Yet, only divisions in phloem parenchyma cells resulted in meristematic regions leading to root primordia. In other studies of micropropagated woody species, sites of origin have been located in cells within or just external to the vascular cambium (Hicks, 1987; Ranjit et al., 1988; Samartin et al., 1986; Vieitez and Vieitez, 1983). In each study, cells leading to root formation could have been phloem parenchyma or cambial derivatives leading to phloem parenchyma. Anatomical studies of difficult-to-root, field-grown stem cuttings of $M$. domestica showed varying levels of primary phloem differentiation into fibers and sclereids in different cultivars. The amount of differentiation correlated well with the difficulty of root induction of the cultivar (Beakbane, 1961, 1969). Our observations and those of Hicks (1987) showed little differentiation of the primary tissue. Most cells in each tissue were parenchymatous. Root induction is frequently easier in micropropagated material (McCown, 1988), perhaps because of the lack of primary phloem differentiation.

First discernible responses to root induction treatment occurred within 1 day and, by 2 days, the response was widespread. The time required for adventitious root initiation in micropropagated material has varied between species, and determination of earliest signs of meristematic activity has been sometimes unclear. Meristematic activity in response to inductive treatments was observed within: 8 days in Camellia japonica L. (camellia, Samartin et al., 1986); 4 days in Rosa xhybrida (rose, Bressan et al., 1982), and 2 days in Prunus avium L. $\times$ Prunus pseudocerasus Lindl. 'Colt' (cherry, Ranjit et al., 1988). In M. pumila, 'KSC-3' (apple rootstock), meristematic activity was seen within 1.5 to 3 days and meristemoids were observed within 5 days of treatment (Hicks, 1987). Detection of earlier signs of meristematic activity in our study may have been due to the thinner sectioning that is possible with epoxy resin-embedded material, which allowed a clearer view of early events.

In microcuttings of 'Gala' apple, only phloem parenchyma cells responded to root induction treatment by forming root primordia. Although other undifferentiated cells (i.e., parenchyma- tous cells of the pith, xylem, cambial region, and cortex) reacted to treatment by cell division, none led to root primordia. This pattern suggests specialization more subtle than the level of differentiation that is involved in the competence of specific cell types to respond to root induction stimuli (IBA + sucrose) with root formation. Recent studies suggest that plants respond to auxins through specific receptor proteins (Klambt, 1990). Moreover, an auxinbinding protein has been correlated with adventitious rooting in tobacco (Nicotiana tabacum L.) callus (Maan et al., 1985). Future studies should combine anatomical characterization of cells competent to form root primordia with immuno-labeling of putative auxin receptors. Tissue-specific location of receptor molecules corresponding to cells capable of forming root primordium could explain cell competence involved in adventitious root formation.

Development of primordia into organized roots occurred during post-induction treatment. Transfer of microcuttings to auxinfree medium resulted in differentiation and organization of tissue systems. Root induction treatments generally include auxin in the medium throughout adventitious root formation. Auxin inhibits root elongation (Went and Thimann, 1937) and can reduce adventitious root formation in microcuttings when applied chronically (James and Thurbon, 1979). The rapid transition to organization and development of primordia observed in this study may be due to lack of auxin in the medium during the development stage.

Multiple-phase rooting protocols are a recent propagation innovation related to improved rooting of some plants (Zimmerman and Fordham, 1985). Treatment selection and timing of application remains unrelated to specific anatomical events. Anatomical observations, such as those presented in this study, reveal events related to rooting and timing to allow refinement of techniques to manipulate final rooting performance. More-specific studies linked to rooting phase response are now possible.

\section{Literature Cited}

Beakbane, A.B. 1961. Structure of the plant stem in relation to adventitious rooting. Nature (London) 192:954-955.

Beakbane, A.B. 1969. Relationships between structure and adventitious rooting. Proc. Intl. Plant Prop. Soc. 19:192-201.

Bressan, O.G., Y.J. Kim, S.E. Hyndman, P.M. Hasegawa, and R.A. Bressan. 1982. Factors affecting in vitro propagation of rose. J. Amer. Soc. Hort. Sci. 107:979-990.

Doud, S.L. and R.F. Carlson. 1977. Effects of etiolation, stem anatomy, and starch reserves on root initiation of layered Malus clones. J. Amer. Soc. Hort. Sci. 102:487-491.

Esau, K. 1977. Anatomy of seed plants. Wiley, New York.

Hackett, W.P. 1988. Donor plant maturation and adventitious root formation, p. 11-28. In: T.D. Davis, B.E. Haissig, and N. Sankhla (eds.). Adventitious root formation in cuttings, Dioscorides, Portland, Ore.

Hackett, W.P. 1985. Juvenility, maturation, and rejuvenation in woody plants. Hort. Rev. 7:109-155.

Haissig, B.E. 1988. Future directions in adventitious rooting research, p. 303-310. In: T.D. Davis, B.E. Haissig, and N. Sankhla (eds.). Adventitious root formation in cuttings, Dioscorides, Portland, Ore.

Harbage, J.F. 1991. Anatomy and physiology of adventitious root formation in Malus domestica microcuttings. PhD Diss., Univ. of Wisconsin, Madison. (Diss. Abstr. 91-28915.)

Hartmann, H.T., D.E. Kester, and J.T. Davies, Jr. 1990. Plantpropagation: Principles and practices. 5th ed. Prentice Hall, Englewood Cliffs, N.J.

Hicks, G.S. 1987. Adventitious rooting of apple microcuttings in vitro: An anatomical study. Can. J. Bot. 65:1913-1920.

James, D.J. and I.J. Thurbon. 1979. Rapid in vitro rooting of the apple rootstock M.9. J. Hort. Sci. 54:309-311.

Johansen, D.A. 1940. Plant microtechnique. 1st ed. McGraw-Hill, New York.

Klambt, D. 1990. A view about the function of auxin-binding proteins at 
plasma membranes. Plant Mol. Biol. 14:1045-1050.

Lovel, H.L. and J. White. 1986. Anatomical changes during adventitious root formation, p. 111-140. In: M.B. Jackson (ed.). New root formation in plants and cuttings. Martinus Nijhoff, Dodrecht, Netherlands.

Lyrene, P.M. 1981. Juvenility and production of fast-rooting cuttings from blueberry shoot cultures. J. Amer. Soc. Hort. Sci. 106:396-398.

Maan, A.C., P.C.G. van der Linde, P.A.A. Harkes, and K.R. Libbenga. 1985. Correlation between the presence of membrane-bound auxin binding and root regeneration in cultured tobacco cells. Planta 164:376378.

McCown, B.H. 1988. Adventitious rooting in tissue cultured plants, p. 289-302. In: T.D. Davis, B.E. Haissig, and N. Sankhla (eds.). Adventitious root formation in cuttings, Dioscorides, Portland, Ore.

Murashige, T. and F. Skoog. 1962. A revised medium for rapid growth and bioassays with tobacco tissue cultures. Physiol. Plant. 15:473-479.

Ranjit, M., D.E. Kester, and V.S. Polito. 1988. Micropropagation of cherry rootstocks: III. Correlations between anatomical and physiological parameters and root initiation. J. Amer. Soc. Hort. Sci. 113: 155-159.

Rugini, E. and D.C. Verma. 1982. Micropropagation of difficult-to- propagate almond (Prunus amygdalus, Batsch) cultivars. Plant Sci. Lett. 28:273-281.

Samartin, A., A.M. Vieitez, and E. Vieitez. 1986. Rooting of tissue cultured camellias. J. Hort. Sci. 61:113-120.

Spurr, A.R. 1969. A low-viscosity epoxy resin embedding medium for electron microscopy. J. Ultrastruct. Res. 26:31-43.

Sriskandarajah, S., M.G. Mullins, and Y. Nair. 1982. Induction of adventitious rooting in vitro in difficult-to-propagate cultivars of apple. Plant Sci. Lett. 24: 1-9

Swingle, C.F. 1927. Burrknot formation in relation to the vascular system of the apple stem. J. Agr. Res. 34:533-544.

Torrey, J.A. 1966. The initiation of organized development in plants. Adv. Morphogenesis. 5:39-91.

Vieitez, A.M. and M.L. Vieitez. 1983. Secuencia de cambios anatomicos durante la rizogenesis in vitro de1 castano. Phyton 43: 185-191.

Went, F.W. and K.V. Thimann. 1937. Phytohormones. Macmillan, New York.

Zimmerman, R.H. and I. Fordham. 1985. Simplified method for rooting apple cultivars in vitro. J. Amer. Soc. Hort. Sci. 110:34-38. 